\title{
TRŽIŠNA PRIHVATLJIVOST GRAĐEVINSKOG MATERIJALA S MALIM UDJELOM UGLJIKA - DIO II: ZAKONODAVNI OKVIR
}

\author{
Tihomir Dokšanović \\ Sveučilište Josipa Jurja Strossmayera u Osijeku, Građevinski fakultet Osijek, mag.ing.aedif. \\ Mario Farkaš \\ Artifex d.o.o. Čepin, mag.ing.aedif. \\ Nataša Njegovanović \\ Sveučilište u Zagrebu, Studij dizajna pri Arhitektonskom fakultetu, student
}

\begin{abstract}
Sažetak: Hrvatska je, kao skorašnja članica Europske Unije i potpisnica Kyotskog protokola, svoje zakonodavstvo značajno usmjerila prema smanjenju emisija stakleničkih plinova i općenito zaštiti prirodnog okoliša. Zakoni vezani uz prirodni okoliš isprepleteni su sa zakonima koji utječu na građevne proizvode, a naravno time i na materijale $s$ malim udjelom ugljika - oni uvelike utječu na njihovu tržǐ̌nu prihvatljivost. Njihovo aktivno provođenje i popularizacija nužni su kako bi se doprinijelo težnjama unaprjeđenja stanja okoliša i prirode Hrvatske, a posljedično i položaja unutar Europske Unije i Sustava za trgovinu emisijama. Kroz članak je pružen pregled zakonodavnog okvira Hrvatske vezanog uz materijale s malim udjelom ugljika koji su predstavljeni u prvom dijelu ovoga rada, a predstavljeni su i određeni prijedlozi za poboljšanje trenutačnog stanja.
\end{abstract}

Ključne riječi: održiva gradnja, tržište, EU direktiva, zakon, pravilnik, certifikat

\section{MARKET ACCEPTANCE OF LOW-CARBON BUILDING MATERIALS - PART II: LEGISLATIVE FRAMEWORK}

\begin{abstract}
Since Croatia is soon to become a member of the European Union and is a signatory of the Kyoto Protocol, its legislation is significantly directed towards reducing greenhouse gas emissions and protecting the environment in general. The laws related to the environment are intertwined with the laws that affect buildingmaterials, and thus low-carbon materials - they greatly affect their market acceptance. Their effective implementation and popularization are required in order to contribute to the aspirations of improving the Croatian environment and nature, and consequently Croatian position in the European Union and the Emissions trading system. This article provides an overview of the Croatian legislative framework related to low carbon content materials, which are presented in the first part of this paper, and presents specific proposals to improve the current situation.
\end{abstract}

Key words: sustainable building, market, EU directive, bill, regulation, certificate 


\section{Uvod}

Hrvatska nije iznimka kada je u pitanju trend porasta stakleničkih plinova (slika 1), a zakone vezane uz prirodni okoliš, odnosno njegovu zaštitu, intenzivno je „proizvodila“ zbog različitih nametnutih obveza koje su proizašle iz želje za pristupanjem određenim procesima. To je posebno naglašeno prilikom pristupnih pregovora za ulazak Hrvatske u Europsku Uniju, koja je poznata po snažnim propisima kada je riječ o prirodnom okolišu.

Zaključivanjem Sporazuma o stabilizaciji i pridruživanju [1] Hrvatska je postala pridruženom članicom Europske Unije. Člankom 69. navedenog Sporazuma Hrvatska se obvezuje na usklađivanje postojećih zakona i budućeg zakonodavstva s pravnom stečevinom Zajednice, a člankom 103. obvezuje se da će razvijati i osnažiti svoju suradnju u borbi protiv uništavanja okoliša radi promicanja njegove održivosti. Sporazum je sklopljen 2001. godine, a 2005. godine stupio je na snagu, nakon ratifikacije u EU parlamentu i Hrvatskom saboru. U ekološkom smislu, radi se o značajnom dokumentu kojim se prihvaćaju osjetno stroži zakoni o energetskoj učinkovitosti, recikliranju, zagađenju okoliša i slično.

Kyotski protokol [2] je drugi obvezujući važniji dokument vezan uz područje zagađenja prirodnog okoliša kojega je Hrvatska potpisala 2007. godine kao 170. država potpisnica. Ratifikacijom Protokola Hrvatska se obvezala na smanjenje emisija stakleničkih plinova za najmanje $5 \%$ ispod razina iz 1990. godine, u razdoblju od 2008. do 2012. godine. Već 2003. godine ukupna emisija plina $\mathrm{CO}_{2}$ je premašila dopuštenu vrijednost obveze iz Kyotskog protokola, kao što je vidljivo na slici 1, no do isteka dogovorenoga razdoblja emisije su bile unutar granica dopuštenoga [3]. Drugo obvezujuće razdoblje, od 2013. do 2020. godine, zahtijeva smanjenje emisija stakleničkih plinova od 20 \% u odnosu na 1990. godinu, a Hrvatska će kao skorašnja članica Europske Unije sudjelovati u njemu [3].

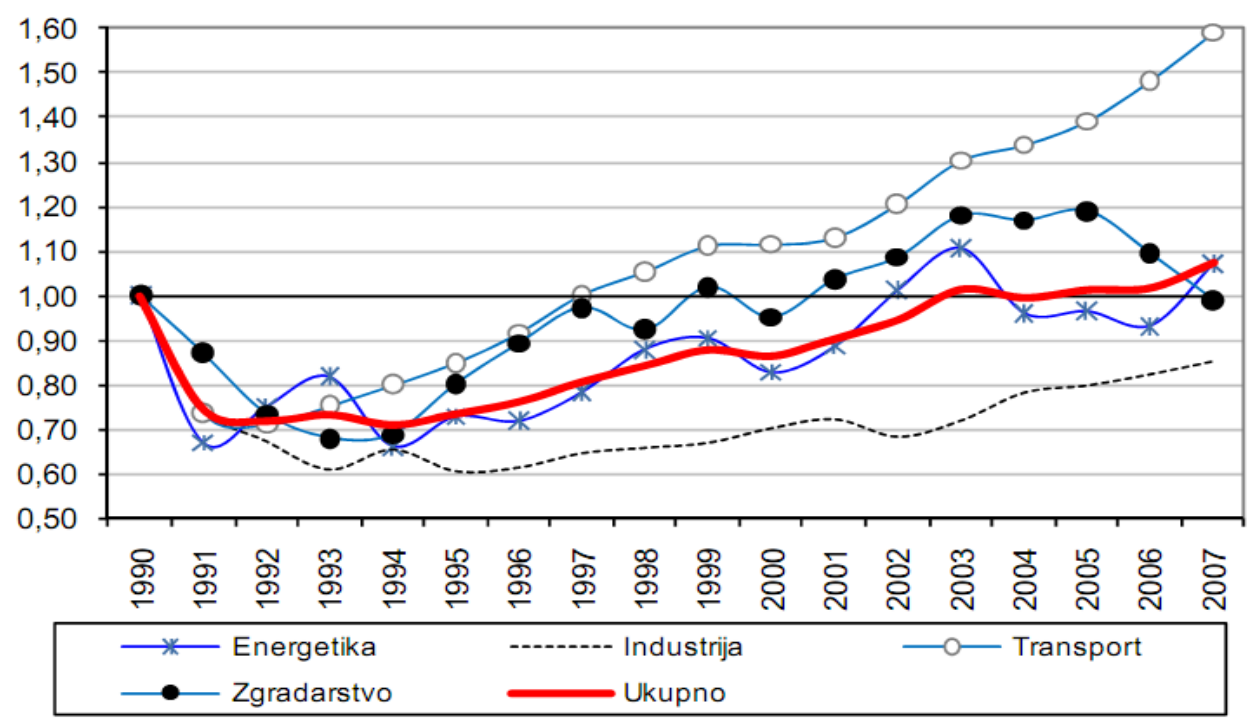

\section{Slika 1 - Emisije $\mathrm{CO}_{2}$ u Hrvatskoj od 1990. do 2007. godine[4]}

Državna tijela izravno povezana uz zakone o materijalima s malim udjelom ugljika su Ministarstvo gospodarstva, Ministarstvo zaštite okoliša i prirode i Ministarstvo graditeljstva i prostornoga uređenja, a „instrumenti“ takvih tijela u Hrvatskoj su Agencija za zaštitu okoliša i Fond za zaštitu okoliša i energetsku učinkovitost. Upravo navedena tijela, uz „instrumente“, trebaju osigurati sve ono što zahtijeva Kyotski protokol i EU, a prema Strategiji energetskog razvoja Republike Hrvatske [5] upravo zgradarstvo je ključna točka uspjeha u tim pothvatima (slika 2).

Zakoni vezani uz prirodni okoliš isprepleteni su sa zakonima koji utječu na građevne proizvode, a naravno time i na materijale s malim udjelom ugljika - oni im zapravo osiguravaju tržište. Zakoni koji su usmjereni ka 
održivosti i „zelenim“ proizvodima imaju za svrhu ojačati održivu gradnju kroz njihovo aktivno provođenje u kontekstu poticanja, informiranja, certificiranja, restrikcija, recikliranja, itd.

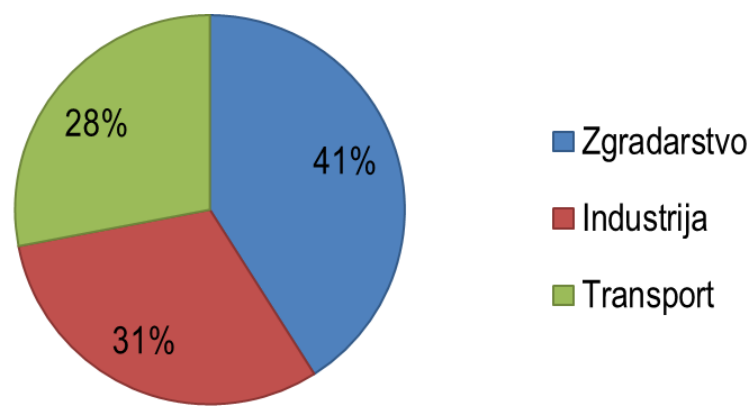

\section{Slika 2 - Potrošnja energije po sektorima u zemljama Europske Unije prema [4]}

Kako bi se pridonijelo težnjama unaprjeđenja stanja okoliša i prirode Hrvatske, te posljedično položaja unutar Europske Unije i sustava za trgovinu emisijama, nužno in je popularizirati. U skladu s time, svrha ovoga članka je pružiti pregled zakonodavnog okvira Hrvatske vezanog uz materijale s malim udjelom ugljika koji su predstavljeni u prvom dijelu [6] ovoga rada, te ponuditi određene prijedloge za poboljšanje trenutačnog stanja.

\section{EU Direktive}

Direktiva je pravni akt Europske Unije, a njome se država obvezuje na ispunjenje određenog cilja, uz to da se nacionalnim vlastima prepušta izbor oblika i metode provedbe. Uz direktivu o građevnim proizvodima, koja je izravno ili neizravno vezana uz građevne materijale s malim udjelom ugljika, Hrvatska je u kontekstu direktiva usmjerenih ka održivoj gradnji, usvojila i direktive koje se odnose na područje toplinske zaštite, uštede energije i zaštitu okoliša vezano za izgradnju, rekonstrukciju i sanaciju zgrada. Osim toga, usvojene bitne direktive su one o učinkovitom korištenju energije u neposrednoj potrošnji i energetskim uslugama i o obnovljivim izvorima energije. Uspostavljanjem navedenih direktiva, Europska Unija ponajviše želi ostvariti zacrtane ciljeve vezane uz smanjenje emisija stakleničkih plinova i povećanje udjela obnovljivih izvora energije u bruto neposrednoj potrošnji. Radi se o ambicioznim ciljevima, od kojih su najviše istaknuti [4]:

- do 2020. godine smanjiti emisiju stakleničkih plinova za $20 \%$ u odnosu na 1990. godinu

- $20 \%$ udjela obnovljivih izvora energije u bruto neposrednoj potrošnji do 2020. godine

- pomoću mjera energetske učinkovitosti ostvariti smanjenje neposredne potrošnje energije od 9\% do 2016. godine.

Uporaba materijala s malim udjelom ugljika izravno se uklapa u strategije o smanjenju emisija štetnih plinova i time predstavlja način ispunjenja strategija Europska Unije.

\subsection{Direktiva 2010/31/EU o energetskim svojstvima zgrada}

U zgradama postoji veliki potencijal za energetske uštede pa je stoga, poradi iskorištavanja toga potencijala, Europski parlament 2010. godine prihvatio Direktivu 2010/31/EU [7]. Kroz 31 članak i 5 priloga planira se poboljšanje energetskih svojstava zgrada na razini cijele Unije uspostavljanjem trajnih i jedinstvenih mehanizama. lako se njome prvenstveno želi smanjiti potrošnja energije, istovremeno se potiče uporaba obnovljivih i alternativnih energetskih sustava. Pomoću ove Direktive uspostavlja se temeljni zakonodavni dokument koji u sektor zgradarstva uvodi [8] okvir za metodologiju proračuna energetskih svojstava zgrada, primjenu minimalnih zahtjeva energetske učinkovitosti za nove zgrade i rekonstrukcije, energetsku certifikaciju zgrada i nezavisni sustav kontrole energetskih certifikata i izvještaja. Prema [4], najvažniji zahtjevi Direktive za države članice Europske Unije su: 
- Države članice trebaju uspostaviti ili, ako postoje, revidirati vlastite minimalne standarde energetske učinkovitosti i primjenjivati in za nove zgrade i postojeće veće zgrade kada su podvrgnute većoj rekonstrukciji.

- Države članice trebaju osigurati dostupnost certifikata zgrada pri izgradnji, prodaji ili iznajmljivanju, tako da ga vlasnik zgrade može dati na uvid potencijalnim kupcima ili najmoprimcima. Savjeti o tome kako poboljšati energetsko svojstvo zgrade trebaju biti dio certifikacije.

- Države članice trebaju osigurati da zgrade u kojima djeluju njihova tijela (državna i lokalna) i institucije koje pružaju javne usluge velikom broju osoba, a imaju uporabnu ploštinu veću od $500 \mathrm{~m}^{2}$, izlože certifikat 0 energetskom svojstvu na vidljivom i istaknutom mjestu. Zgrade uporabne ploštine veće od $250 \mathrm{~m}^{2}$ bit cee obuhvaćene ovom obvezom od 9. srpnja 2015.

- Države članice trebaju uspostaviti sustav za redovite preglede i ocjenjivanje sustava za grijanje, ventilaciju i klimatizaciju.

- Države članice trebaju osigurati da nakon 31. prosinca 2018. sve nove zgrade u vlasništvu tijela javne vlasti budu s gotovo nultom potrošnjom energije, a sve nove zgrade neovisno o vlasništvu isto dostignu nakon 31 . prosinca 2020.

\subsection{Direktiva 89/106/EEZ i Uredba 305/2011 o građevnim proizvodima}

Kako bi se u području graditeljstva osigurala sloboda kretanja roba, koja je spomenuta u Sporazumu o stabilizaciji i pridruživanju, unutar Unije je još 1988. godine usvojena Direktiva 89/106/EEC [9]. Njome se usklađuju tehnički zahtjevi za građevne proizvode na razini cijele Unije tako da proizvod proizveden u jednoj od država članica mora biti takav da se može ugrađivati u drugim članicama. Osim usklađivanja zahtjeva vezanih uz proizvod, nužno je uskladiti i da se u drugim članicama primjenjuju isti zahtjevi na građevine i na način ugradnje proizvoda. Kako bi se navedeno omogućilo, Direktiva određuje [10]:

- bitne zahtjeve za građevinu, koji su jednaki za sve države članice

- uporabljive građevne proizvode, kao one koji svojim svojstvima osiguravaju ispunjavanje bitnih zahtjeva za građevinu, uz uvjet da oni sami zadovoljavaju određene zahtjeve i da su ispravno ugrađeni.

lako je uvođenje ove direktive bilo problematično zbog potrebnih usklađivanja zakona, zahtjevi koji se njome postavljaju ugrađeni su u Zakon o građevnim proizvodima [11]. Revizijom Direktive o građevnim proizvodima 24. travnja 2011. nastala je Europska uredba o građevnim proizvodima CPR №.305/2011 [12]. Tim datumom počelo je i prijelazno razdoblje u kojemu se jednakovrijedno primjenjuju odredbe Direktive i Uredbe sve do 1. srpnja 2013., kada će se ukinuti Direktiva i u potpunosti primjenjivati Uredba. S obzirom na to da se radi o Uredbi, ona će se izravno primijeniti kao zakon u svim državama članicama Unije. Osnovne razlike između Direktive koja se ukida i Uredbe vezane su uz terminologiju, a njome se želi postići jednostavnija i time učinkovitija primjena propisa vezanih za građevne proizvode.

\subsection{Sustav trgovanja emisijama stakleničkih plinova}

Još jedna od, u kontekstu materijala s malim udjelom ugljika, bitnih i poticajnih odredbi Europske Unije je ETS (Emissions Trading System), međunarodni Sustav za trgovanje emisijama stakleničkih plinova. Uspostavom ovog Sustava, koji je zasnovan na Direktivi 2003/87/EC [13] i pokrenut 2005. godine, želi se ograničiti i u konačnici smanjiti ukupne iznose emisija stakleničkih plinova. Sustav funkcionira po načelu godišnje trgovine emisijama stakleničkih plinova preko vršnih vrijednosti emisija. Drugim riječima, postoji određena vršna vrijednost emisije stakleničkih plinova u radu tvornica, elektrana i sličnoj industriji, kojom svaka od njih raspolaže i može trgovati. Primjerice, ako neka tvornica ispušta manje plinova od svoje vršne vrijednosti za recimo 15\%, taj „višak“ može prodati nekoj drugoj tvornici koja premašuje vršnu vrijednost emisije ili ostaviti sebi kao mogućnost ostvarenja prekoračenja emisija sljedeće godine. Sve instalacije obuhvaćene ETS-om na kraju godine moraju imati razinu emisija ispod kvote, bilo kroz vlastite kvote proizvodnje ili uz kupljene postotke zaliha drugih instalacija. Ako se instalacije ne pridržavaju navedene granice, dužne su platiti novčane kazne. Vršne vrijednosti emisija $s$ vremenom se smanjuju kako bi i ukupna emisija stakleničkih plinova bila stalno u padu, a poradi toga da u 2020. 
godini emisije iz sektora obuhvaćenih ETS-om budu za $21 \%$ niže u odnosu na 2005. godinu. ETS se trenutačno provodi u 30 zemalja (27 članica Europske Unije uz Hrvatsku, Island, Lihtenštajn i Norvešku) [14], a obuhvaća emisije $\mathrm{CO}_{2}$ iz proizvodnje električne i toplinske energije, industrijskih ložišta, rafinerija nafte, čeličana, te proizvodnje željeza, aluminija, cementa, vapna, stakla, keramike, celuloze, papira, kartona, kiselina i rasutih organskih kemikalija.

Hrvatska je postala dio ovoga sustava od 1.siječnja 2013., a zakonske osnove za uvođenje ETS-a postavljene su u Zakonu o zaštiti zraka [15] i Uredbi o emisijskim kvotama stakleničkih plinova i načinu trgovanja emisijskim jedinicama [16]. Time će građevni proizvodi s malom razinom ugljika postati i industrijski poželjni, jer će njihovi proizvođači moći izbjeći naknade ili čak uspjeti zaraditi na trgovini neiskorištenih vrijednosti emisija stakleničkih plinova.

\section{Zakoni i propisi}

lako su zakoni povezani s građevnim materijalima s malim udjelom ugljika proizvod direktiva, a često se i pozivaju na određene direktive, pomoću njih je moguće lakše prikazati kakve su mogućnosti, odnosno kakva je podloga za provedbu određenih postupaka prikazanih u prvom dijelu [6] ovoga rada. Zbog velikog broja zakona nije nužno opširnije navoditi njihov sadržaj s obzirom na to da su dostupni u izdanjima Narodnih novina, a oni važniji su sljedeći: Zakon o prostornom uređenju i gradnji [17], Zakon o Fondu za zaštitu okoliša i energetsku učinkovitost [18], Zakon o građevnim proizvodima [11], Pravilnik o tehničkim dopuštenjima za građevne proizvode [19], Pravilnik o nadzoru građevnih proizvoda [20], Tehnički propis o građevnim proizvodima [21] i Zakon o zaštiti zraka [15]. Za u [6, 22] spomenute rezerve zgure i loma opeke, u Hrvatskoj postoji zakonska osnova za uporabu. Prema Pravilniku o vrstama otpada [23] na popisu otpada nalaze se građevni otpad i otpad od rušenja objekata (uključujući otpad od izgradnje cesta) te anorganski otpad iz termičkih procesa, u koje se, prema Katalogu otpada iz istog pravilnika, uvrštavaju navedeni materijali. Pravilnikom o gospodarenju otpadom [24] omogućuje se uporaba takvih materijala, a u Tehničkom propisu za betonske konstrukcije [25] navodi se kako je u obliku agregata moguće koristiti materijale dobivene preradom prirodnih, industrijski proizvedenih ili recikliranih materijala i mješavina tih agregata u pogonima za proizvodnju agregata, ako uz uvjet zadovoljenja zahtjeva za [22] geometrijskim, fizičkim, kemijskim i trajnosnim svojstvima prema normi HRN EN 12620:2008 - Agregati za beton.

\section{Certificiranje}

Certifikati su zamišljeni kao potvrde o sukladnosti određenih svojstava proizvoda s pravilima i zahtjevima tog certifikata. U Hrvatskoj je ocjenjivanje sukladnosti građevnih proizvoda sastavni dio zakona, ali postoji još mnogo postupaka certificiranja koji su primjenjivi u Hrvatskoj, a u kontekstu građevnih materijala s malim udjelom ugljika bi bili korisniji. Naime, prema određenim certifikatima, materijal ugrađen u zgradu izravno utječe na konačnu ocjenu same zgrade. 


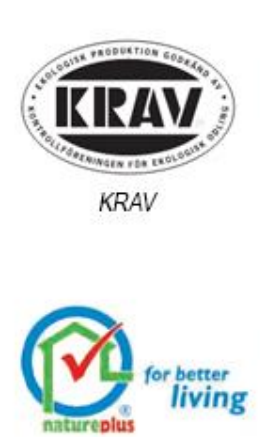

Nature Plus
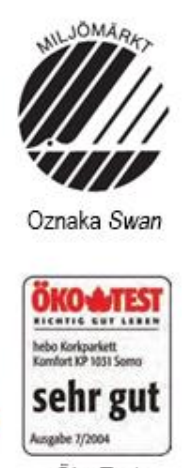

Ōko Test
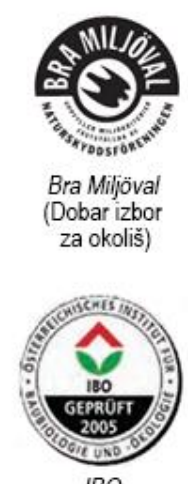

$I B O$

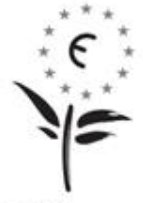

EU flower

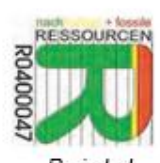

R-simbol

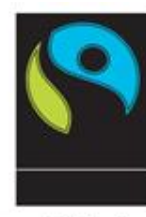

Fair Trade

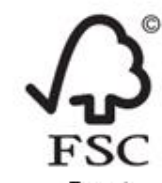

Forest

Stewardship Council

Slika 3 - Razne oznake certifikata za ekološki povoljne materijale [26]

Osim certifikata zgrada, postoje i certifikati za materijale (slika 3) pomoću kojih je moguće uvidjeti da je određeni materijal ekološki povoljan, što ne znači da je on dobar za okoliš, nego da stvara manje štetnih učinaka od sličnih proizvoda koji ne ispunjavaju taj certifikat.

\subsection{Certificiranje zgrada}

Sustavi ocjenjivanja, odnosno certificiranja razvijeni su kako bi se mogla kvantificirati razina održivosti zgrada. Pri takvom ocjenjivanju promatraju se parametri kao što su oblikovanje prostora, izgradnja i korištenje, a sam certifikat u konačnici pruža vlasnicima i korisnicima zgrada informaciju o energetskim i ostalim ekološkim svojstvima zgrade, ovisno o vrsti certifikata. Naime, neki sustavi certificiranja pokrivaju samo određene kriterije održivosti zgrada poput energetske učinkovitosti, a neki cijeli pristup zelenoj gradnji promatrajući kriterije poput održivosti lokacije, zdravlja ljudi i okoliša, odabira materijala, ekološke kvalitete interijera, društvenog utjecaja i ekonomičnosti zgrade. Za svaki kriterij postoji jedno ili više mjerila kvalitete koja se moraju dokazati kako bi se dobio određeni broj bodova tj. ispunili zahtjevi. Ovisno o samom sustavu, individualno se boduju pojedine stavke te se na taj način određuje konačna ocjena zgrade. Pregled različitih sustava certificiranja zgrada u svijetu prikazan je u tabeli 1.

Certificiranje prema ranije spomenutoj EU Direktivi [7] (slika 4) koje se u Hrvatskoj provodi, kao dio ocjene zgrade ne uključuje ekološku podobnost materijala korištenih tijekom izgradnje, odnosno ocjenjuje samo energetsku učinkovitost zgrade u njezinom eksploatacijskom vijeku.
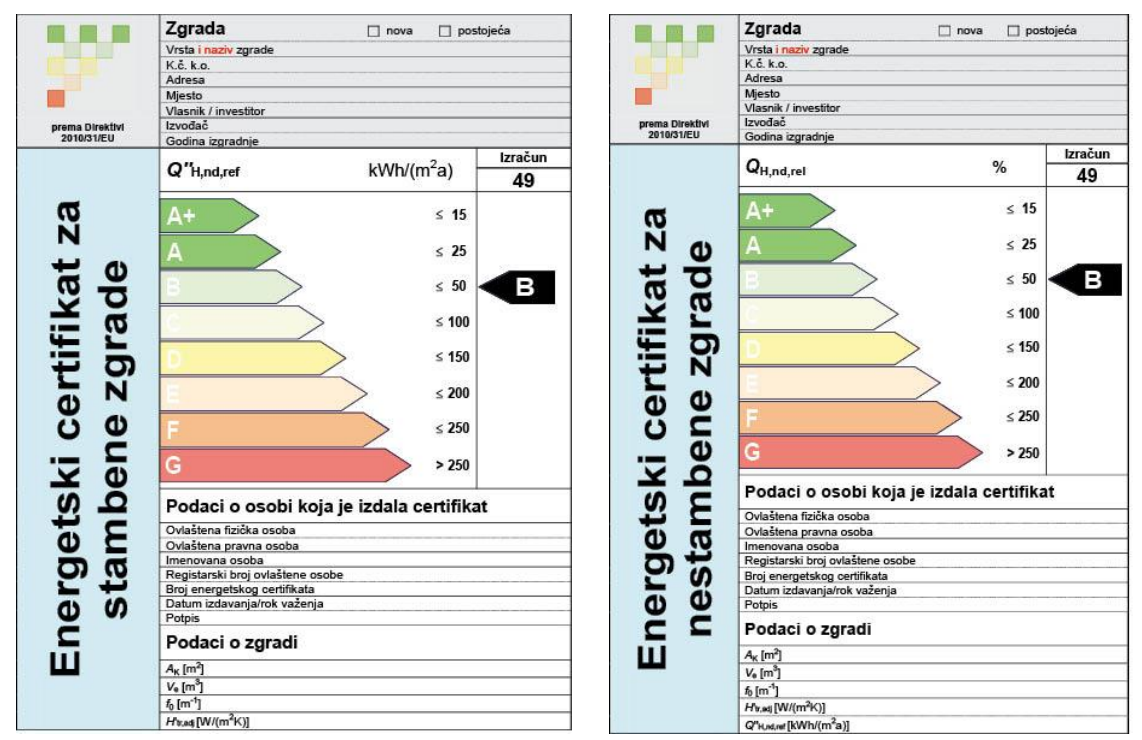


\section{Slika 4 - Izgled prve stranice energetskog certifikata za stambene i nestambene zgrade u Hrvatskoj [28]}

Time se iz ocjene izuzima energetska vrijednost ugrađenih materijala, koja je karakteristika pomoću koje se može bolje ocijeniti ukupna štetnost zgrade na okoliš. Praćenjem te vrijednosti može se potaknuti uporaba materijala s nižim energetskim vrijednostima, što jamči manje otpuštanja stakleničkih plinova čije smanjenje je neizravan cilj direktive. Implementiranjem te stavke u sadašnji pravilnik, dobila bi se bolja slika ukupne energetske vrijednosti pojedine građevine, kao što je to slučaj kod sustava certificiranja BREEAM, LEED, Green Star i sličnih.

Tabela 1 - Usporedba različitih sustava certificiranja zgrada prema [27]

\begin{tabular}{|c|c|c|c|c|}
\hline $\begin{array}{c}\text { Sustav } \\
\text { certificiranja } \\
\text { (Zemlja podrjetla) }\end{array}$ & Osnovan & Ključni parametri procjene & Inačice za & Ocjene \\
\hline $\begin{array}{c}\text { DGNB } \\
\text { (Njemačka) }\end{array}$ & 2007. & $\begin{array}{l}\text { - Ekološka kvaliteta } \\
\text { - Ekonomska kvaliteta } \\
\text { - Društvena kvaliteta } \\
\text { - Tehnička kvaliteta } \\
\text { - Kvaliteta procesa } \\
\text { - Kvaliteta lokacije }\end{array}$ & $\begin{array}{l}\text {-Poslovne zgrade } \\
\text { - Stambene zgrade } \\
\text { - Industrijske objekte } \\
\text { - Trgovačke objekte } \\
\text { - Postojeće zgrade } \\
\text { - Obrazovne ustanove }\end{array}$ & $\begin{array}{l}\text { Bronca } \\
\text { Srebro } \\
\text { Zlato }\end{array}$ \\
\hline $\begin{array}{c}\text { BREEAM } \\
\text { (Vellka Britanija) }\end{array}$ & 1990. & $\begin{array}{c}\text { - Zdravlje i dobrobit } \\
\text { - Energija } \\
\text { - Voda } \\
\text { - Materijali } \\
\text { - Ekologija lokacije } \\
\text { - Zagađenje } \\
\text { - Transport } \\
\text { - Zauzeće zemljišta } \\
\text { - Upravljanje }\end{array}$ & $\begin{array}{c}\text {-Sudove } \\
\text { - Pasivne kuće } \\
\text { - Obrazovne ustanove } \\
\text { - Zdravstvene ustanove } \\
\text { - Industrijske objekte } \\
\text { - Trgovačke objekte - } \\
\text { Stambene zgrade } \\
\text { - Poslovne zgrade } \\
\text { - Zatvore }\end{array}$ & $\begin{array}{l}\text { Prolaz } \\
\text { Dobro } \\
\text { Vrlo dobro } \\
\text { Odlično } \\
\text { Izvanredno }\end{array}$ \\
\hline $\begin{array}{l}\text { LEED } \\
\text { (SAD) }\end{array}$ & 1998. & $\begin{array}{c}\text { - Održivost lokacije } \\
\text { - Učinkovitost uporabe vode } \\
\text { - Energija i atmosfera } \\
\text { - Materijali i resursi } \\
\text { - Kvaliteta unutarnjeg zraka } \\
\text { - Inovacije i oblikovanje prostora }\end{array}$ & $\begin{array}{c}\text {-Novogradnje } \\
\text { - Postojeće zgrade } \\
\text { - Kuće } \\
\text { - Obrazovne ustanove } \\
\text { - Trgovačke objekte }\end{array}$ & $\begin{array}{l}\text { LEED Ovjereno } \\
\text { LEED Srebro } \\
\text { LEED Zlato } \\
\text { LEED Platina }\end{array}$ \\
\hline $\begin{array}{l}\text { Green Star } \\
\text { (Australia) }\end{array}$ & 2003. & $\begin{array}{c}\text { - Upravljanje } \\
\text { - Udobnost interijera } \\
\text { - Energija } \\
\text { - Transport } \\
\text { - Voda } \\
\text { - Materijali } \\
\text { - Zauzeće zemljišta i ekologija } \\
\text { - Emisije } \\
\text { - Inovacije }\end{array}$ & $\begin{array}{l}\text {-Postojeće poslovne } \\
\text { zgrade } \\
\text { - Nove poslovne zgrade }\end{array}$ & $\begin{array}{c}4 \text { zvjezdice; } \\
\text { Najbolja praksa } \\
5 \text { zvjezdica; } \\
\text { Australijska } \\
\text { izvrsnost } \\
6 \text { zvjezdica; } \\
\text { Svjetski } \\
\text { predvodnik }\end{array}$ \\
\hline
\end{tabular}




\begin{tabular}{|c|c|c|c|c|}
\hline $\begin{array}{l}\text { CASBEE } \\
\text { (Japan) }\end{array}$ & 2001. & $\begin{array}{c}\text { - Energetska učinkovitost } \\
\text { - Učinkovitost uporabe resursa } \\
\text { - Okoliš zgrade } \\
\text { - Unutrašnjost zgrade }\end{array}$ & $\begin{array}{c}\text { - Sve vrste zgrada i } \\
\text { objekta }\end{array}$ & $\begin{array}{c}\text { C (slabo) } \\
B \\
B^{+} \\
A \\
\text { S (odlično) }\end{array}$ \\
\hline $\begin{array}{l}\text { Minergie } \\
\text { (Švicarska) }\end{array}$ & 1988. & $\begin{array}{c}\text { - Krivulja gustoće građenja } \\
\text { - Učinkovitost sustava grijanja } \\
\text { - Kvaliteta ventilacije } \\
\text { - Krivulja zračne nepropustljivosti } \\
\text { zgrade } \\
\text { - Učinkovitost uređaja u zgradi } \\
\text { - Ekološka gradnja (optimizirani uvjeti } \\
\text { tijekom dana, niska razina buke i } \\
\text { zagađenja) }\end{array}$ & $\begin{array}{c}\text { - Sve vrste zgrada i } \\
\text { objekta }\end{array}$ & $\begin{array}{c}\text { Minergie } \\
\text { Minergie-P } \\
\text { Minergie-Eko } \\
\text { Minergie-P-Eko }\end{array}$ \\
\hline
\end{tabular}

Utjecaj određenih parametra na konačnu ocjenu zgrada prema LEED (Leadership in Energy and Environmental Design), BREEAM (BRE Environmental Assessment Method) i DGNB (German Sustainable Building Certificate - GeSBC) sustavima certificiranja prikazan je na slikama 5, 6 i 7.

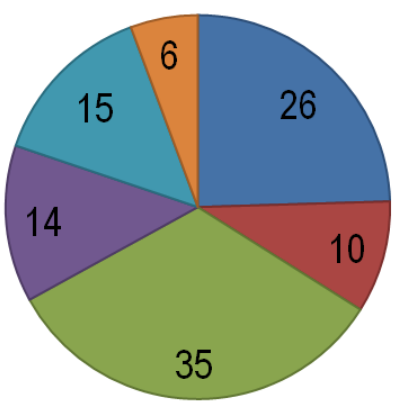
$\square$ Održivost lokacije
- Iskorištavanje vode
$\square$ Energija i atmosfera
$\square$ Materijali i resursi
$\square$ Kvaliteta unutarnjeg okruženja
$\square$ Inovacije u oblikovanju prostora

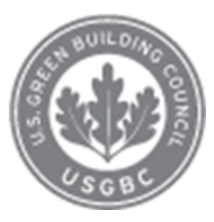

Slika 5 - Utjecaj parametara procjene na konačnu ocjenu zgrade prema LEED-u

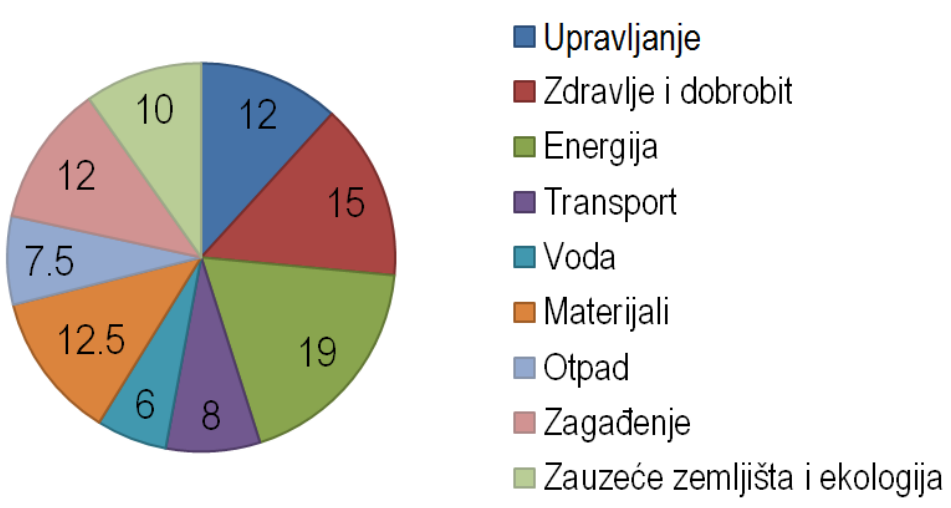

breeam

Slika 6 - Utjecaj parametara procjene na konačnu ocjenu zgrade prema BREEAM-u 

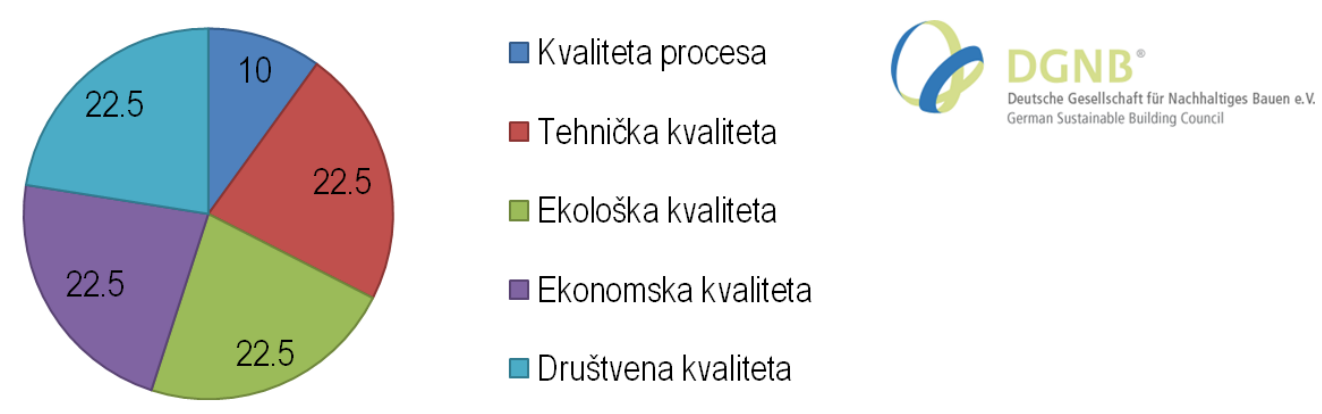

Slika 7 - Utjecaj parametara procjene na konačnu ocjenu zgrade prema DGNB-u

\subsection{Certificiranje materijala}

Za potvrde sukladnosti ekološki povoljnih proizvoda (materijala) u svijetu postoji veliki broj certifikata od kojih su neki prikazani na slici 3, a u Hrvatskoj je za tu svrhu razvijen certifikat Prijatelj okoliša (slika 8). Radi se 0 certifikatu koji je proizvod međunarodne prakse, a po postupku dodjeljivanja njegova znaka obuhvaća sve ono što obuhvaćaju i svjetski certifikati. Navedeni znak pokazuje da se poštuju visoki standardi zaštite okoliša iznad propisanog zakonskog minimuma, a proizvođač i svi drugi sudionici u dodjeli znaka zaštite okoliša sudjeluju dragovoljno, želeći pokazati sve što su učinili glede smanjenja onečišćenja okoliša, utroška sirovina i energije [29]. Prema Ministarstvu zaštite okoliša i prirode, znak je manje važan za one proizvode koji po prirodi stvari imaju malen ili zanemariv utjecaj na okoliš, stoga je u prvom redu usmjeren na skupine proizvoda i usluga potencijalno štetnih za okoliš, kako bi se poticao razvoj alternativnih proizvoda i usluga koji imaju manje štetan utjecaj tijekom životnog ciklusa.
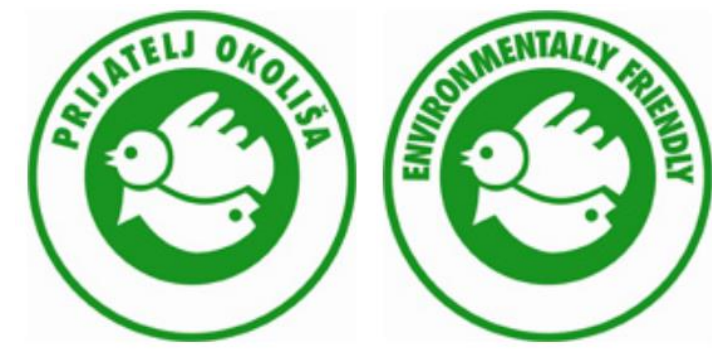

\section{Slika 8 - Znak hrvatskog certifikata za ekološki povoljne proizvode [29]}

Pri procjeni proizvoda proizvođača koji su podnijeli zamolbu za dobivanje znaka zaštite okoliša, uzimaju se u obzir sve faze životnog ciklusa proizvoda. To uključuje potrošnju sirovine i energije, emisije onečišćavanja, stvaranja otpada, mogućnost recikliranja, kao i mogućnost i potrebu odlaganja - ugrađena energija proizvoda. U svakoj fazi ispituju se i procjenjuju svi mogući štetni utjecaji za okoliš.

Znak zaštite okoliša dodjeljuje se najdulje na rok od tri godine, a nakon isteka roka proizvođač može podnijeti novu zamolbu za produljenje prava na korištenje znaka. Inspektor zaštite okoliša u inspekcijskom nadzoru nadzire udovoljava li proizvod kojemu je dodijeljen znak zaštite okoliša mjerilima. Postupak, način dodjele, uvjeti za dobivanje znaka zaštite okoliša, izgled, uporaba i rok važenja dodijeljenog znaka, sastav i način rada povjerenstva za dodjelu znaka, te sudjelovanje pojedinaca, udruga i organizacija u postupku dodjele znaka zaštite okoliša propisani su Pravilnikom o znaku zaštite okoliša [30]. 


\section{Prijedlozi za poticanje i mjere poboljšanja tržišne zastupljenosti materijala s malim udjelom ugljika}

Kako je temeljna zadaća uporabe građevinskih materijala s malim udjelom ugljika smanjiti emisije štetnih plinova, količinu otpada te uporabu prirodnih materijala, a temeljna zadaća države da pruži potporu takvim naporima, najbolji način na koji treba prići ovom problemu jest poticanje, poboljšanje primjene postojećih zakona i informiranje stanovništva i proizvođača o dostupnim poticajima, postojećim zakonima i potrebi korištenja istih. Naime, naša Vlada stalno postavlja pitanje kako odvojiti stvaranje nove vrijednosti od ovisnosti o ugljiku i fosilnim gorivima, znajući da energetske potrebe u Hrvatskoj rastu, a između ostalog, upravo „zeleni“ proizvođači, usklađeni u naporima, odgovor su na to pitanje.

Vladama svijeta, a tako i našoj, dostupni su razni instrumenti kako potaknuti „zelenu“ gradnju i proizvode, bilo da se radi o instrumentima kontrole i nadzora, fiskalnim instrumentima ili instrumentima informiranja (tabela 2). Što god da se odabere kao primarna politika, svakako je jasno da se mora učiniti više nego dosada kako bi se ohrabrilo proizvođače i kako bi se osigurao veći udjel ekološki prihvatljivijih materijala na tržištu.

Ako odgovarajući podupirući okvir postoji i pravilno funkcionira, tada će se povećati tržišna vrijednost energetski učinkovitih zgrada i tržišna zastupljenost materijala $s$ malim udjelom ugljika. Ulaganja u sektor „zelenog“ će rasti, a društvo zasigurno napredovati.

Tabela 2 - Dostupni instrumenti poticanja ,zelenih“ proizvoda prema [31]

\begin{tabular}{|r|c|c|}
\hline & $\begin{array}{c}\text { učinkovitost u } \\
\text { smanjenju emisija }\end{array}$ & ekonomičnost \\
\hline Kontrolni i nadzorni instrumenti & visoka & visoka \\
\hline standardi primjene proizvoda & visoka & visoka \\
\hline programi certificiranja & visoka & visoka \\
\hline zadane razine energetske učinkovitosti & & visoka \\
\hline Fiskalni instrumenti i poticaji & visoka & visoka \\
\hline nulta stopa poreza ili redukcije poreza & & srednje visoka \\
\hline dobrovoljna certifikacija & & \\
\hline
\end{tabular}

Kada je u pitanju Hrvatska, nije potrebno uspostavljati nove kriterije ocjenjivanja ekološke prihvatljivosti materijala jer, kao što je ranije navedeno, oni postoje i obuhvaćaju u sebi pojmove kao što su resursi, učinkovitost i onečišćenje, odnosno sve što takvi pojmovi podrazumijevaju kako bi ocjena materijala bila cjelovita i vjerodostojna. Općenito postoji okvir kroz standarde i certificiranje, ali on nije potpun bez povezivanja certificiranja sa sustavom poticanja i smanjenja poreza za proizvođače koji proizvode građevne materijale s malim udjelom ugljika. Upravo kroz poticaje i niže poreze proizvođačima, takvi materijali mogu biti konkurentniji na tržištu, uz sve prednosti prikazane u [6]. Osim toga, potrebno je osnažiti razinu komunikacije između raznih zainteresiranih struka koje mogu proizvoditi građevne materijale s malim udjelom ugljika.

\subsection{Osnaživanje komunikacije}


S obzirom na to da je održiva gradnja splet različitih struka i procesa, prvo je potrebno osnažiti komunikaciju svih zainteresiranih strana. Kroz komunikaciju, osnažile bi sve sastavnice održive gradnje, a materijali bi se, kao „izvor i kraj", prepoznali kao tržišno bitno.

Vlada treba uspostaviti registar tvrtki koje imaju nakane ili već proizvode materijale s malim udjelom ugljika kako bi se omogućila lakša sklapanja partnerstva i razmjena iskustava, što može pomoći u daljnjem proboju na tržištu sa zajedničkim ciljem. Naime, suradnja tvrtki koje proizvode takve materijale omogućila bi lakši proboj na tržište, kroz zajedništvo bi se omogućila i manja cijena proizvoda, izvođači bi prije prepoznali vrijednost takvih proizvoda, a i općenito stanovništvo bi lakše uvidjelo viši, ekološki cilj.

Konferencije i seminari trebaju biti osnova edukacije svih zainteresiranih profesionalaca kako bi uvidjeli koje su prednosti gradnje s takvim materijalima i kako se korištenjem takvih materijala ne odstupa od redovite prakse. Ovdje su zasigurno pozitivni primjeri „Forum o održivoj gradnji“ i projekt „Ugljični otisak - trag odgovornosti“, ali potrebno je mnogo više takvih događaja.

Nadalje, potrebno je osigurati medijski prostor kroz kampanje o održivoj gradnji i prednostima zelenih materijala nad konvencionalnima, a zasigurno i oglašavati trenutačni sustav certificiranja materijala jer bi time dobio na važnosti. Naime, trenutačni sustav certificiranja materijala Prijatelj okoliša predstavlja „mekani instrument" u politici zaštite okoliša, dakle promotivno sredstvo, ali nije prepoznatljiv u široj javnosti, što je ministarstvo i samo priznalo [32].

Kako bi se izgradilo povjerenje između izvođača i proizvođača, potrebno je uspostaviti jamstva za zelene proizvode ako se koriste u većim količinama na jednom projektu, naravno uz nadzor ugradnje i održavanja. Naime, izvođači često smatraju kako su zeleni materijali lošiji ili manje trajni zbog toga što su novi i stoga nemaju dokazanu pouzdanost.

\subsection{Prilagodba trenutačnog zakonskog okvira}

Preko dostupnog, navedenog sustava certificiranja zelenih materijala, moguće je odrediti koji su to materijali prema ugrađenoj energiji „zeleni“, odnosno bolji od svojih konvencionalnih inačica. Nakon utvrđivanja radi li se o takvom materijalu, lako je takvu klasifikaciju uzeti kao zakonsku podlogu za primjenu sustava poticaja ili poreznih olakšica za njhove proizvođače, kako bi im se omogućilo lakše poslovanje. Uz takvu klasifikaciju materijala, zakonski priznatu, moguće je i preko bankarskog sustava s olakšanim kriterijima za kredite i povoljnijim kamatama subvencionirati proizvođače u nabavi opreme za proizvodnju takvih materijala.

Isto tako, kao mogućnost pojeftinjenja proizvodnje zelenih inačica konvencionalnih materijala koji koriste reciklirane sirovine u proizvodnji, treba razmotriti uvođenje zakonske obveze da se pri projektiranju, kao dio projektne dokumentacije, zahtijeva plan reciklaže, ponovnog korištenja i odlaganja materijala dobivenih rušenjem zgrade nakon isteka njezinog projektnog životnog vijeka. Ako na mjestu gradnje treba rušiti neki objekt, prije izgradnje novoga treba izraditi takav plan i za taj objekt. Ako bi se ovakva zakonska obveza uvela, tada bi se mogli osigurati ugovori s određenim proizvođačima građevnih materijala s malom razinom ugljika da otpad od rušenja uklanjanju i kroz proizvodnju novih materijala jamče ispunjenje tog dijela projektne dokumentacije.

\section{Zaključak}

Građevinski materijali s niskim udjelom ugljika zasigurno imaju budućnost na današnjem tržištu jer njihova uporaba predstavlja put ka ispunjavaju velikoga broja obveza koje je Hrvatska preuzela po pitanju zaštite prirode i kvalitete zraka. Zadaća države jest da pruži potporu naporima poboljšanja položaja takvih materijala, a najbolji načini na koje se to može učiniti jesu poticanje, poboljšanje primjene postojećih zakona i informiranje stanovništva i proizvođača o dostupnim poticajima, postojećim zakonima i potrebi korištenja istih. Treba učiniti više nego dosada kako bi se ohrabrilo proizvođače i kako bi se osigurao veći udjel ekološki prihvatjjivijh materijala na tržištu.

Proizvodnja takvih materijala je osigurana unutar zakonskog okvira, a prednosti naglašene kroz taj zakonodavni okvir i stajalište društva o takvim materijalima. Dostupni sustavi certificiranja zelenih materijala 
trebaju se iskoristiti i povezati sa zakonodavnom podlogom sustava poticaja ili poreznih olakšica za njihove proizvođače kako bi im se omogućilo lakše poslovanje.

\section{Zahvala}

Ovaj članak predstavlja dio rada „Tržišna prihvatljivost građevinskog materijala s niskim udjelom ugljika" s kojim su autori sudjelovali na projektu CaseStudyCompetition 2011 u okviru poslovnog slučaja poduzeća Holcim (http://www.gfos.hr/portal/index.php/novosti/1441-case-study-competition-2011.html). Ovim putem autori se zahvaljuju tvrtki Holcim i udruzi e-Student zbog kojih je rad i nastao, te Društvu građevinskih inženjera Osijek na financijskoj potpori. Osim toga, autori se zahvaljuju doc.dr.sc. Zlati Dolaček-Alduk na potpori, korisnim savjetima i literaturi tijekom pisanja rada, te dr.sc. Krunoslavu Minažeku i dr.sc. Ivani Barišić na korisnim savjetima i literaturi.

\section{Literatura}

[1] Sporazum o stabilizaciji i pridruživanju između Republike Hrvatske, s jedne strane, i Europskih zajednica i njihovih država članica, $s$ druge stane, NN 14/01

[2] Kyotski protokol uz Okvirnu konvenciju Ujedinjenih naroda o promjeni klime, NN 5/07

[3] Ministarstvo zaštite okoliša i prirode. Druga radionica na temu izrade okvira za Strategiju nisko-ugljičnog razvoja Hrvatske. 2012 [Mrežna stranica pregledana 25.02.2013.]; http://klima.mzoip.hr/default.aspx?id=352

[4] Mikulić, D., et al., Energetsko certificiranje zgrada. Građevinar, 2010. 62(12): p. 1087-1096.

[5] Strategija energetskog razvoja Republike Hrvatske, NN 130/09

[6] Dokšanović, T.; Farkaš, M.; Njegovanović, N., Tržišna prihvatljivost građevinskog materijala s malim udjelom ugljika, Dio I: Materijali i mogućnosti smanjenja utjecaja na okoliš. e-GFOS, 2012. 3(5): p. 1-20.

[7] European Commission, Directive 2010/31/EU of the European Parliament and of the Council of 19 May 2010 on the energy performance of buildings (recast). Official Journal of the European Union, L153, 2010. 53: p. $13-35$.

[8] Energetski institut Hrvoje Požar. Direktiva 2010/31/EU o energetskim svojstvima zgrada. 2010 [Mrežna stranica pregledana 20.02.2013.]; http://www.eihp.hr/hrvatski/detaljnije.php?Tip=zanimljivost\&id=2457

[9] European Commission, Council Directive 89/106/EEC of 21 December 1988 on the approximation of laws, regulations and administrative provisions of the Member States relating to construction products. Official Journal of the European Union, L40, 1989. 32: p. 12-26.

[10] Fučić, L.; Štromar, Ž., Direktiva o građevnim proizvodima - izazovi uvođenja. Građevinar, 2006. 58(12): p. 1009-1019.

[11] Zakon o građevnim proizvodima, NN 86/08, 25/13

[12] European Commission, Regulation (EU) No 305/2011 of the European Parliament and of the Council of 9 March 2011 laying down harmonised conditions for the marketing of construction products and repealing Council Directive 89/106/EEC. Official Journal of the European Union, L88, 2011. 54: p. 5-43.

[13] European Commission, Directive 2003/87/EC of the European Parliament and of the Council of 13 October 2003 establishing a scheme for greenhouse gas emission allowance trading within the Community and amending Council Directive 96/61/EC. Oficial Journal of the European Union, No: L275, 2003. 46: p. 32-46.

[14] European Commission. The EU Emissions Trading System (EU ETS). 2013 [Mrežna stranica pregledana 23.02.2013.]; http://ec.europa.eu/clima/policies/ets/index_en.htm

[15] Zakon o zaštiti zraka, NN 130/11

[16] Uredba o emisijskim kvotama stakleničkih plinova i načinu trgovanja emisijskim jedinicama, NN 142/08, $113 / 10$

[17] Zakon o prostornom uređenju i gradnji, NN 76/07, 38/09, 55/11, 90/11, 50/12

[18] Zakon o Fondu za zaštitu okoliša i energetsku učinkovitost, NN 107/03, 144/12

[19] Pravilnik o tehničkim dopuštenjima za građevne proizvode, NN 103/08

[20] Pravilnik o nadzoru građevnih proizvoda, NN 113/08

[21] Tehnički propis o građevnim proizvodima, NN 33/10, 87/10, 146/10, 81/11, 100/11, 130/12 
[22] Netinger, I., Predgotovljeni armiranobetonski elementi povećane požarne otpornosti, 2010, Sveučilište J.J. Strossmayera u Osijeku: Osijek.

[23] Pravilnik o vrstama otpada, NN 27/1996

[24] Pravilnik o gospodarenju otpadom, NN 23/07, 111/07

[25] Tehnički propis za betonske konstrukcije, NN 139/09, 14/10, 125/10, 136/12

[26] Bokalders, V.; Block, M., The whole building handbook: how to design healthy, efficient, and sustainable buildings, 2010, London, England, UK: Earthscan.

[27] Bauer, M.; Mosle, P.; Schwarz, M., Green Building - Guidebook for Sustainable Architecture, 2007, Stuttgart, Germany: Springer.

[28] Pravilnik o energetskim pregledima građevina i energetskom certificiranju zgrada, NN 81/12, 29/13

[29] Ministarstvo zaštite okoliša i prirode. Znak zaštite okoliša. 2013 [Mrežna stranica pregledana 27.02.2013.]; http://www.mzoip.hr/default.aspx?id=5396

[30] Pravilnik o znaku zaštite okoliša, NN 70/08

[31] World Business Council for Sustainable Development, Energy Efficiency in Buildings Business realities and opportunities, 2007, World Business Council for Sustainable Development.

[32] Biološka raznolikost i biološka sigurnost. Promicati hrvatski znak zaštite okoliša - "Prijatelj okoliša". 2005 [Mrežna stranica pregledana 12.04.2011.];

http://www.gmo.hr/index.php/vijesti/promicati_hrvatski_znak_zastite_okolisa_prijatelj_okolisa 